\title{
How candidate characteristics matter : Candidate profiles, political sophistication, and vote choice
}

\section{Coffe, Hilde}

2021-05-01

Coffe , H \& von Schoultz , Å 2021, ' How candidate characteristics matter : Candidate profiles, political sophistication, and vote choice ', Politics : surveys and debates for students of politics , vol. 41 , no. 2 , 0263395720922077 , pp. 137-155 . https://doi.org/10.1177/0263395720922077

http://hdl.handle.net/10138/332892

https://doi.org/10.1177/0263395720922077

unspecified

acceptedVersion

Downloaded from Helda, University of Helsinki institutional repository.

This is an electronic reprint of the original article.

This reprint may differ from the original in pagination and typographic detail.

Please cite the original version. 


\title{
HOW CANDIDATE CHARACTERISTICS MATTER: CANDIDATE PROFILES, POLITICAL SOPHISTICATION, AND VOTE CHOICE
}

Manuscript accepted for publication in Politics: https://journals.sagepub.com/home/pol

Hilde Coffé, University of Bath, $\underline{\text { H.R.Coffe@ bath.ac.uk }}$

Åsa von Schoultz, University of Helsinki, asa.vonschoultz@ helsinki.fi

\begin{abstract}
This article examines the influence of various candidate characteristics (sociodemographic profile, competence and experience, issue positions, and party affiliation) on voters' preference for a candidate, and investigates the impact of voters' levels of political sophistication on their likelihood to considering various candidate characteristics voters when deciding whom to support. Using data from the 2015 Finnish National Election Study, the study is situated within the complex Finnish open list system with many candidates at display and mandatory preference voting. We find that voters mostly argue to make their choice based on candidate characteristics with direct politically relevant information such as candidate party affiliation and issue positions. Candidate sociodemographic profile has relatively little stated impact. Overall, voters with higher levels of political sophistication tend to be more likely to consider a broad range of candidate characteristics. When investigating the relative impact of each candidate characteristic (that is, their impact relative to the other candidate characteristics) on voting behaviour, political sophistication increases the likelihood of saying to rely on candidate characteristics that are more demanding in terms of information processing such as competence and experience, and issue positions. Our analyses also show how different measures of political sophistication have distinct effects.
\end{abstract}




\section{INTRODUCTION}

Political behaviour scholars seem to have reached a consensus that the personalization of politics constitutes an ongoing trend in Western democracies, with the profiles of leaders and candidates playing an increasingly important role in citizens' voting behaviour (e.g., Garzia 2014; McAllister 2007). As the link between voters and parties has weakened, voters have substituted their partisanship with other factors in their electoral decision-making process, notably the assessment of party candidates and leaders (Dalton and Wattenberg 2000; Wattenberg 1991).

Despite this suggested trend of personalization, relatively little research has systematically compared the extent to which various candidate characteristics influence voters' preferences for candidates. Most existing research has focused on how candidate gender affects voters' likelihood of supporting candidates (e.g. Campbell and Cowley 2014; Coffé and Theiss-Morse 2016; Dolan and Lynch 2014; Koch 2002; Rosenthal 1995; Trent et al. 2001). Some other studies have looked at the effect of candidate personality traits or appearance (e.g. Berggren et al. 2010; Catellani and Alberici 2012; Clifford 2014; Johns and Shephard 2007; Lenz and Lawson 2011; Peterson 2005), as well as candidates' local roots, visibility and political experience on electoral behaviour (Collignon and Sajuria 2018; Put and Maddens 2015; Shugart et al. 2005; Tavits 2010).

With the exception of a few recent experimental studies (Arnesen et al. 2019; Franchino and Zucchini 2015; Kirkland and Coppock 2018; Pedersen et al. 2019) focusing on the impact of candidates' sociodemographic characteristics and issue positions on voting behaviour, relatively little is known about the extent to which the impact of a wide variety of characteristics differs. For example, we know little about the extent to which voters focus on candidate sociodemographic characteristics, and how it compares with other candidate characteristics, such as issue positions, and party affiliation. Therefore, the aims of the current study are (1) to investigate which candidate characteristics voters say to consider when choosing which candidate to vote for, and (2) to examine how these considerations differ depending on voters' levels of political sophistication. To do so, we rely on the 2015 Finnish National Election Study (Grönlund and Kestilä-Kekkonen 2015). With its system of open-list proportional representation with mandatory preferential voting, Finland is a complex electoral context. In particular, a high number of nominated candidates competing for votes on individual platforms but within the framework of strong and relevant parties makes the system demanding for voters to navigate.

We compare which emphasis voters place on candidate sociodemographic profile, competence and experience, issue positions, and party affiliation when deciding whom to vote for. By analysing which characteristics voters take into account when making their choice, we can gain a deeper understanding of voters' decision-making processes and behaviour, and its consequential influence on the make-up of legislatures. We argue that characteristics that are strongly related to substantive aspects of politics (such as candidates' party affiliation, competence and experiences, and issue positions) will be prioritized by voters, despite the observed trend towards partisan dealignment and the complexity voters face when deciding whom to vote for with many candidates at display. In addition, we expect 
politically sophisticated voters to be more likely to consider candidate characteristics that are more challenging in terms of information processing compared with less politically sophisticated voters.

\section{THEORY}

\section{The Impact of Candidate Characteristics}

How do voters decide which candidate to vote for when there are many candidates at display? Previous research has pointed towards the use of various voting cues to navigate the complexities of the political information available, and as such facilitate the decision-making process. Adam and Maier (2010) state that personalization works by clustering political information about a candidate into characteristics, which then act as information shortcuts for voters. The more complex and information-rich the electoral environment is, the more responsive voters tend be to simple cues that allow them to reduce the time and effort devoted to deciding how to vote (Lau and Redlawsk 2006).

One such simple cue is a candidate's sociodemographic profile. The vast majority of research examining the influence of candidate sociodemographic characteristics on voting has concentrated on the effect of gender. Some studies conclude that citizens' inherent gender stereotypes affect their likelihood of supporting a female candidate (e.g. Koch 2002; Rosenthal 1995). However, other research finds that gender has little influence on candidate preferences (e.g. Campbell and Cowley 2014; Coffé and Theiss-Morse 2016; Dolan and Lynch 2014; Trent et al. 2001). Looking at sociodemographic characteristics other than gender, research has shown that candidate occupational background (Coffé and Theiss-Morse 2016) is considerably more relevant to voting decisions than gender, while age does not appear to affect voters' candidate preferences (Campbell and Cowley 2014). Candidate level of education has also been found to influence voting behaviour (Campbell and Cowley 2014), with a candidate who left school at age 18 surprisingly favoured by voters in comparison with a candidate who had obtained a university degree. Some research (Pedersen et al. 2019) has also demonstrated that voters infer both personal traits and policy positions from sociodemographic characteristics of candidates.

A more demanding type of decision-making process is a focus on substantive matters such as candidate competence and experience, and issue positions. Research by political psychologists suggests that citizens are well practiced in assessing political candidates based on their personality, given that people habitually utilize others' personality in order to evaluate and form an impression of the person (Fridkin and Kenney 2011). Voters can make inferences about candidate reliability and ability to manage things through the media, and through candidate campaign messages (Fridkin and Kenney 2011). Information on the personal qualities of a candidate offers voters important insights into how the candidate may perform while in office (Miller et al. 1986). Focusing on personal qualities, most empirical studies have concluded that candidate political and management skills influence voters' opinions and behaviour to a greater extent than non-political aspects (Adam and Maier 2010). Relatedly, there is a great advantage for candidates to be well known to the public. This holds particularly in personalized voting systems such as the Finnish system. Experienced candidates who have accumulated 
a reputation from politics, by previous office holding (Dahlgaard 2016; Kirkland and Coppock, 2018), being acknowledged in the local community (Collignon and Sajuria 2018; Put and Maddens 2015; Shugart et al. 2005), or candidates who are well known from other areas of public life (Arter 2014) tend to win more votes.

Another important characteristic of candidates are their issue positions. These positions, which provide direct political information, are generally expected to influence voters' evaluations of candidates and voting behaviour (Lau and Redlawsk 2001). This is confirmed in a recent conjoint experiment (Arnesen et al. 2019), demonstrating that voters' preference for candidates is influenced more strongly by candidates' issue positions than by their social characteristics (see however Luskin 1990). In the same vein, Franchino and Zucchini (2015) present evidence that policies trump education (and integrity) when voters choose between pairs of candidates. However, a systematic gathering of candidate issue positions for a large pool of potential candidates is highly demanding.

Candidate party affiliation is also a candidate characteristic providing direct and substantive political information, but in a way that is relatively easy for voters to grasp. Despite the movement towards partisan dealignment and the loosening of ties between citizens and political parties, we expect candidate party affiliation to have a strong influence on voting decisions as it provides voters with a strong indication of the path that the candidate would take if elected to office. Looking at evaluations of MPs among a sample of undergraduate students, Johns and Shephard (2007) concluded that partisanship is the dominant influence (see also Hayes and Lawless 2016). Previous research on Finnish voters demonstrates that candidate party affiliation is a decisive factor for about half of the voters when deciding for which candidate to vote (Isotalo et al. 2019). Despite the trend of dealignment, studies show that voters' political affiliation is (still) often the best predictor of their vote choice (e.g. Bafumi and Shapiro 2009; Bartels 2000; Hayes and Lawless 2016).

In sum then, there are different types of candidate characteristics that voters can rely on when deciding which candidate to support. Some of these characteristics, such as sociodemographic profile, and party affiliation, are relatively easy for voters to grasp, and does not crave much in terms of information processing. Others are more demanding, and presume that voters process a great deal of information. This holds in particular for evaluations of issue positions, but also to some extent for competence and experience, especially in an electoral setting with many candidates at display. The candidate characteristics, however, also vary in terms of the political information they contain, where the characteristics with great political substance, such as party affiliation, competence and experience, and issue positions, can be considered as richer in direct political information compared with for example candidate sociodemographic background.

Given that party affiliation is a simple cue with high political relevance, we expect voters to emphasise this characteristic the most when deciding which candidate to support. Candidate competence and experience, and their issue positions are, in turn, expected to have less impact than party affiliation since they tend to be more difficult to decipher. Due to the political relevance of 
competence and experience, and issue positions, we do, however, expect them to have a greater political bearing on voters' selection process than sociodemographic characteristics, which contain less directly politically relevant information. Indeed, while sociodemographic characteristics, such as gender, have been found to influence representatives' parliamentary behaviour and policy focus (e.g. Bolzendahl and Brooks 2007; Childs 2004; Lovenduski 2005; Norris 1996; Wängnerud 2009) and as such contain politically relevant information, the political information that they contain is less straightforward. Therefore, we expect sociodemographic characteristics, to be of lower relevance to voters compared with more concrete and straightforward political pointers, such as candidate party affiliation. In sum, we expect voters to emphasize different candidate characteristics depending on the amount of direct political information they carry, and on how challenging they are in terms of information processing. In particular, our hypotheses read as follows:

H1a: Party affiliation is the candidate characteristic that influences voters the most when they decide whom to support.

H1b: Competence, experience and issue positions are less influential candidate characteristics than candidate party affiliation when voters decide whom to support.

H1c: Sociodemographic characteristics are the candidate characteristics that influence voters the least when they decide whom to support.

\section{Political Sophistication and the Impact of Candidate Characteristics}

The extent to which voters will rely on different candidate characteristics may, however, differ depending on voters' levels of political sophistication. Political sophistication refers to the extent to which a person has knowledge of political activities, understands and assimilates political information, and forms political views. Luskin (1990: 332) writes: "A person is politically sophisticated to the extent to which his or her political cognitions are numerous, cut a wide substantive swath, and are highly organised, or constrained."

Some scholars have argued that politically sophisticated voters evaluate candidates and make their voting decisions in different ways compared with those who are not politically sophisticated (e.g. Bartels 1996; Dalton 1984; Funk 1997; Goren 1997; Johns and Shephard 2007; Popkin 1991; Zaller 1990). Politically sophisticated voters have greater political knowledge, have a greater ability for complex processing of political information and are better able to absorb the complexities of politics (Funk 1997). As put by Sniderman and colleagues (1991, 166):

"It is, in short, not plausible to suppose that the well-informed voter and the poorly informed one go about the business of making up their minds in the same way."

The way in which voters make up their minds is thus likely to vary with voters' levels of political sophistication, and the impact of political sophistication is expected to grow with the complexity of the electoral context (Lau and Redlawsk 2006). In information-rich electoral settings such as the Finnish 
OLPR system with many candidates competing for votes on individual platforms using personalised campaign strategies, voters are overloaded with information, making political sophistication a key factor in information processing.

Various scholars have confirmed that political sophistication leads to greater accessibility of policy attitudes and consequently higher levels of ideological and policy voting, and a greater likelihood of evaluating candidates and parties in policy terms (Delli Carpini and Keeter 1996; Goren 1997; Macdonald et al. 1995). In order for citizens to utilize candidate issue positions as voting cues, they must obviously be informed of and understand candidates' policy positions (Cutler 2002). In addition, they need to know their own opinions on relevant issues and thus be able to conclude whether they agree or disagree with the policy stance taken by candidates. Given that politically sophisticated voters will have a better understanding of candidate policy positions and their own position on relevant issues, they are expected to rely more on candidate policy positions than politically unsophisticated voters. Empirical research has indeed confirmed that higher levels of political sophistication are related to higher levels of voter-party ideological congruence (Boonen et al. 2017; Lau et al. 2013; Singh 2010).

Evaluations of candidates' competence and experiences can be seen as less demanding than evaluations of issue positions, but they do take more information processing compared with party positions and sociodemographic background, especially when there are many candidates for voters to choose from. Brown et al. (1988) suggest that sophisticated voters place greater importance on the characteristics of leaders that are relevant to politicians' ability to do their job, than unsophisticated voters. This finding is consistent with the idea that candidate characteristics, like their issue positions, are harder to decipher and hence may be utilized to a greater extent by politically sophisticated voters who have greater exposure to and understanding of political information.

Based on the above, our hypothesis regarding political sophistication and the tendency to rely on characteristics that require greater political understanding to decipher reads as follows:

H2: Politically sophisticated voters are more likely to be influenced by more complex candidate characteristics such as candidate competence, experience and issue positions when deciding whom to support compared with less politically sophisticated voters.

While empirical research has mostly confirmed that politically sophisticated voters rely more on characteristics that are hard to ascertain, results are inconsistent when it comes to the link between voters' levels of political sophistication and the likelihood of relying on candidate characteristics that are easy to ascertain. For example, candidate party affiliation, and the associated party's reputation, provide a voting cue which is easily ascertainable by almost all voters, except those with no political engagement and interest whatsoever. While one may thus expect - as also suggested by the cognitive mobilization theory (Dalton 1984, 2007) - that candidate party affiliation would be most frequently utilized by less politically sophisticated voters in order to supplement their limited political awareness, 
Kim (2006) finds that in the South Korean case, politically knowledgeable citizens are more likely to rely on partisan cues than unsophisticated voters. Albright (2009) also found that greater political knowledge and exposure to mass media leads to an increase in party attachments (see also Zaller 1992). This suggests that politically sophisticated individuals may be more likely to rely on candidate party affiliation to reach a voting decision.

Similar to candidate party affiliation, candidate sociodemographic characteristics, such as gender and age, are relatively easy to determine. They are observable features which are easily ascertainable by voters from the names and images of candidates and are, as such, easy heuristics (Johns and Shephard 2017). Popkin (1991) confirms that less informed citizens will place greater reliance on sociodemographic cues than more informed citizens since the latter will update their perspectives with material of greater political substance. Similarly, Cutler (2002) concludes that less sophisticated voters are more likely to rely on sociodemographic characteristics. He does, however, also find that more politically sophisticated voters also fall back on sociodemographic characteristics and that they seem to rely on both policy and sociodemographic criteria.

The inconclusive findings for the cognitively simple candidate characteristics of sociodemographic profile and party affiliation is in line with the argument put forward by Sniderman et al. (1991) that better informed voters rely on a broader range of decision criteria than the less well informed. According to Sniderman and colleagues it is hence not necessarily the case that political sophisticates turn to more demanding types of information only, but rather that " [...] the better-informed voter tends to take account of nearly everything including the kitchen sink.” $(1991,173)$.

While the empirical research on the link between political sophistication and the likelihood of relying on cognitively simple candidate characteristics is inconclusive, based on the reasoning of Sniderman et al. (1991) we hypothesise that the effect of political sophistication for these types of characteristics is weak. Our third hypothesis thus reads:

H3: Political sophistication does not influence the tendency of voters to emphasise 'easy' candidate characteristics such as party affiliation and sociodemographic background when deciding whom to support.

Table 1 provides an overview of the different candidate characteristics studied in the current paper, their differences in terms of information processing and the political information they contain, and the emphasis we expect voters to say they put on the different candidate characteristics and how this emphasis is expected to differ depending on voters' levels of political sophistication. 
Table 1. Classification of Candidate Characteristics and Voters' Expected Emphasis on Different Candidate Characteristics

\begin{tabular}{|c|c|c|c|c|}
\hline \multirow[b]{2}{*}{$\begin{array}{l}\text { Candidate } \\
\text { Characteristics }\end{array}$} & \multirow[b]{2}{*}{$\begin{array}{c}\text { Information } \\
\text { Processing }\end{array}$} & \multirow[b]{2}{*}{$\begin{array}{c}\text { Direct } \\
\text { Political } \\
\text { Information }\end{array}$} & \multicolumn{2}{|c|}{ Hypotheses } \\
\hline & & & $\begin{array}{l}\text { Expected } \\
\text { Emphasis }\end{array}$ & $\begin{array}{l}\text { Expected Difference in } \\
\text { Emphasis Depending on } \\
\text { Political Sophistication }\end{array}$ \\
\hline $\begin{array}{l}\text { Sociodemographic } \\
\text { Profile }\end{array}$ & Low & Low & $\begin{array}{l}\text { Low } \\
(\mathrm{H} 1 \mathrm{c})\end{array}$ & $\begin{array}{l}\text { None } \\
(\mathrm{H} 3)\end{array}$ \\
\hline $\begin{array}{l}\text { Competence and } \\
\text { Experience }\end{array}$ & $\begin{array}{l}\text { Medium / } \\
\text { High }\end{array}$ & Medium / High & $\begin{array}{l}\text { Medium } \\
\text { (H1b) }\end{array}$ & $\begin{array}{c}\text { Greater emphasis among } \\
\text { politically sophisticated voters } \\
\text { (H2) }\end{array}$ \\
\hline Issue Positions & High & High & $\begin{array}{l}\text { Medium } \\
\text { (H1b) }\end{array}$ & $\begin{array}{c}\text { Greater emphasis among } \\
\text { politically sophisticated voters } \\
(\mathrm{H} 2)\end{array}$ \\
\hline Party Affiliation & Low & High & $\begin{array}{l}\text { High } \\
\text { (H1a) }\end{array}$ & $\begin{array}{l}\text { None } \\
(\mathrm{H} 3)\end{array}$ \\
\hline
\end{tabular}

\section{DATA AND MEASUREMENTS}

Our study is situated in one of the oldest examples of open-list proportional representation (OLPR) systems, namely Finland. It is a highly candidate-oriented system, but a system with cohesive parties and where party affiliation still matters a great deal for electoral behaviour (Karvonen 2010). Votes are casted directly for individual candidates, and not for a collective party list, but parties nominate candidates and the votes are pooled at the party level (e.g. Karvonen 2010; Marsh 1985). The amount of seats won by a party is determined by the total amount of votes for the candidates nominated by the party in the district (13 in the 2015 Parliamentary Election), and the seats are filled by the candidates with the highest number of personal votes. The system is characterised by duality in terms of electoral competition, with equally strong competition between parties (inter-party competition) and between candidates running for the same party (intra-party competition) (von Schoultz 2018). It is also a complex system for voters to navigate, since there are many candidates at display. Parties are allowed to nominate 14 candidates, or as many candidates as there are seats to be filled, and the system incentivises parties to run full lists (von Schoultz, 2018). In the 2015 election, the number of nominated candidates in the largest electoral district of Uusimaa was 394.

Due to the competition across and within parties, and the many nominated candidates from which the voters have to choose a single candidate, the system provides voters with a highly complex choice set-up. This, in turn, is believed to make voters more responsive to simple cues that allow them to reduce the time and effort devoted to deciding how to vote (Lau and Redlawsk 2006).

To investigate the importance of different candidate characteristics in voters' decision-making process and examine the extent to which this importance differs depending on voters' levels of political sophistication, we use the 2015 Finnish National Election Study (Grönlund and Kestilä-Kekkonen 
2015). While all elections take place in their specific context, the 2015 Finnish parliamentary election can be considered as a 'regular' Finnish election. As in many other European democracies, the Finnish party system has become more fragmented and polarised over the last two decades, with the electoral breakthrough of the populist radical-right Finns Party in the 2011 election being the most dramatic change. These developments have made voters more aware of differences across parties, and more likely to take into account the party affiliation of candidates when deciding which candidate to vote for compared with 15 years ago (Isotalo et al. 2019).

The Finnish National Election Study is a national representative cross-sectional survey performed in two stages involving face-to-face interviews based on quota sampling (according to age, gender, and province of residence). The original dataset consists of 1,587 respondents. Of those respondents, 291 said they had not voted at the 2015 elections. These non-voters are not included in the analyses. We also excluded respondents who voted blank $(\mathrm{N}=2)$. Other respondents with missing information on any of the independent variables (except the left-right scale) have been deleted listwise, giving a final sample size of 1,173 respondents. ${ }^{1}$

Data were weighted using the variable provided with the data set. The variable weights the sample to match mother tongue, age, gender, and electoral district distributions in the population as well as the actual vote share of parties in the elections. All results presented below are provided for weighted data.

\section{Dependent Variables}

To grasp the extent to which voters take various candidate characteristics into account when deciding which candidate to support, we use a question asking respondents to ascertain the extent to which a selection of characteristics influenced for which candidate they decided to vote. Note that the answers to the question do not say whether respondents voted for someone with the same characteristics (e.g., age, gender, party affiliation) as the respondent. We ran some explorative analyses investigating the link between the extent to which age and gender influenced voters' choice of a candidate and respectively whether they voted for someone who is of the same gender (yes/no) and what the age was of the candidate they voted for (roughly the same age - much younger - much older). These analyses revealed that those who voted for a candidate of the same gender and - to a lesser extent - age are more likely to find respectively gender and age a decisive factor in their candidate preference than those who did not vote for a candidate of the same gender.

Subjective evaluations of personal behaviour should be interpreted with some caution. As demonstrated in previous research such answers may be subject to rationalisation; voters may report reasons that sound rational and systematic and fail to mention considerations based on emotions (Rahn et al. 1994). Voters may also be unaware of the true motives for their choice (Nisbett and Wilson 1977).

\footnotetext{
${ }^{1}$ The number of respondents does vary slightly between the different dependent variables.
} 
Some scholars have, however, suggested that an introspective approach provides valuable information regarding citizens' behaviour (Kelley, 1983; Blais et al. 1998). The use of survey questions such as the one used here also overcomes the major deficiency of survey experiments often used in studies on the effect of candidate characteristics, namely that the results may have limited validity outside the context of the experiment. Asking respondents directly about their preferences can give a better representation of which candidate characteristics matter most in real-life situations.

Based on a principal component factor (PCF) analysis (Table $\mathrm{A}$ in the Appendix), the substantive meaning of items, and the internal inconsistency (measured through Cronbach's Alpha) of possible scales, we operationalized four different (groups of) characteristics: sociodemographic profile, competence and experience, issue positions, and party affiliation. ${ }^{2}$ As such, the study looks at a diverse range of characteristics, including characteristics which are more difficult to ascertain (e.g. competence and issue positions) and those which are easier to understand and discern (e.g. party affiliation and demographic characteristics). It also includes measures that have direct political relevance (e.g. party affiliation and issue positions) and characteristics that do not have such direct relevance and may seem more 'superficial' (e.g. sociodemographic profile).

The measure of candidate sociodemographic profile relies on three items: age, gender, and education (Cronbach's Alpha: .64). Four items are used to measure perceived competence and political experience of the candidate: reliability, ability to manage things, public speaking and presentation skills, and prior experience in politics (Cronbach's Alpha: .79). Issue positions and Party affiliation are both measured by a single item. The answer categories were: (1) decisive factor in my choice; (2) a lot; (3) somewhat; (4) not at all. Answers were re-coded in such a way that higher values refer to greater importance.

\section{Explanatory Variables}

Political sophistication has been measured in various ways in empirical research and has been linked to citizens' exposure (the political information citizens receive), their motivation (citizens' interest in learning about politics), and their intelligence (their ability to assimilate and organize political information) (Luskin 1990). While most empirical research has focused on the effect of one specific measure of political sophistication, we investigate the effect of three different measures simultaneously: political knowledge, political interest, and media exposure. While we did not formulate specific hypotheses for each specific measure of political sophistication (but rather formulated hypotheses on the effect of political sophistication overall) in our theoretical section, testing the effect of different

\footnotetext{
${ }^{2}$ A PCF analysis including the nine candidate background characteristics included in the current study revealed two factors with an eigenvalue higher than one. Party affiliation however loaded poorly on the two factors. Therefore, we decided to include it as a separate component. Given that a candidate's views on different issues seems substantively different from the other items scoring high on Factor 1 as presented in Table A in the Appendix, we also decided to include it as a separate candidate characteristic.
} 
measures of political sophistication allows an empirical examination of which measure of political sophistication has the greatest impact on the relevance of various candidate characteristics. Political knowledge measures factual knowledge about politics and is a sum scale that relies on four multiple choice questions asking respondents the name of the Finnish Minister of Finance right before the 2015 parliamentary elections, the name of the party with the second largest number of seats in the newly elected parliament, the name of the current Secretary-General of the United Nations, and the meaning of a parliamentary system of government (Cronbach's Alpha: .50). The variable measures the number of correct answers. The second measure of political sophistication is political interest and relies on a question asking respondents how interested they are in politics. Answer categories ranged from (1) very interested to (4) not interested at all, but are recoded in such a way that a higher value refers to greater political interest. The third and final measure of political sophistication is media attention and relies on a question asking the respondents how much attention they paid to media coverage of the parliamentary elections. We distinguish two measures operationalized as sum scales. The first one measures traditional media use and includes seven items: television debates and party leader interviews, television news and current affairs programmes, television entertainment programmes featuring politicians, radio programmes, newspaper articles, columns or letters to the editor, and television advertisements and newspaper advertisements (Cronbach's Alpha: .74). The second scale refers to online media use and also includes seven items: web news covering elections (e.g. newspaper websites), candidate and political party websites, blogs, candidate selectors on the internet, social media (e.g. Facebook, Twitter or Instagram), videos of the candidates or political parties on the internet (e.g. YouTube), and news broadcasts on the internet or social media (Cronbach's Alpha: .85). ${ }^{3}$ Answer categories for each individual item were: a great deal of attention, a fair amount of attention, only a little, paid no attention at all. They are recoded in such a way that higher scores refer to greater attention.

\section{Control Variables}

In the analyses below, we also include a series of common sociodemographic and political control variables known to affect electoral behaviour. Table B in the appendix provides an overview of the control variables. Table $\mathrm{C}$ in the Appendix introduces descriptive information for all explanatory variables and control variables included in the analyses.

\footnotetext{
${ }^{3}$ A PCF analysis including the 14 ways of following the election campaign revealed four components, combining all types of online media use in one component but distinguishing the traditional media in three different components. A PCF analysis only including the traditional media however revealed that the eigenvalues of the second and third component were close to one. Furthermore, Cronbach's Alpha confirmed high internal consistency when all seven types of traditional media use are combined (and did not increase if one of the items was deleted). Therefore, we decided to combine all seven items measuring traditional media use in one scale.
} 


\section{Analytical Strategy}

To investigate the link between political knowledge and the relevance of candidate characteristics when voters decide whom to support, we performed Ordinary Least Squares (OLS) regression analyses for each of the dependent variables introduced above. ${ }^{4}$

\section{ANALYSES}

\section{Descriptive Analyses}

Before investigating explanatory patterns through a multivariate analysis, Table 2 presents the means (and standard deviations) for the four candidate characteristics investigated in the current study. Table $\mathrm{D}$ in the Appendix provides more detailed results with the percentages per answer category.

Table 2. Descriptive Data for Importance Candidate Characteristics

\begin{tabular}{|c|c|c|c|c|}
\hline & \multirow[t]{2}{*}{ Range } & \multicolumn{2}{|c|}{ Total } & \multirow[t]{2}{*}{ Total $\mathbf{N}$} \\
\hline & & Mean & Std. Dev. & \\
\hline Sociodemographic Profile & $1-4$ & 1.82 & .69 & 1,166 \\
\hline Age & $1-4$ & 1.76 & .86 & 1,171 \\
\hline Gender & $1-4$ & 1.68 & .94 & 1,169 \\
\hline Education & $1-4$ & 2.01 & .92 & 1,169 \\
\hline Competence and Experience & $1-4$ & 2.73 & .74 & 1,139 \\
\hline Reliability & $1-4$ & 2.94 & .90 & 1,159 \\
\hline Ability to Manage Things & $1-4$ & 3.02 & .88 & 1,167 \\
\hline \multicolumn{5}{|l|}{ Public Speaking and } \\
\hline Presentation Skills & $1-4$ & 2.50 & .94 & 1,161 \\
\hline \multicolumn{5}{|l|}{ Prior Experience in } \\
\hline Politics & $1-4$ & 2.40 & 1.00 & 1,165 \\
\hline Issue Positions & $1-4$ & 3.03 & .89 & 1,170 \\
\hline Party Affiliation & $1-4$ & 3.08 & .99 & 1,166 \\
\hline
\end{tabular}

As can be seen from Table 2, candidate party affiliation is the most often mentioned factor when voters evaluate how important various characteristics were for them when deciding whom to vote for, confirming Hypothesis 1a. About 45 percent of the respondents (see Table D) state that candidate party affiliation was a decisive factor, indicating that candidate party affiliation (still) plays an important role in voting decisions. As anticipated (Hypothesis 1b), candidate issue positions and competence and experience-scale follow candidate party affiliation as the characteristics that are most frequently considered by voters when deciding whom to vote for. Of the four items included in the competence and experience scale, ability to manage things is emphasised the most, followed by reliability. In line

\footnotetext{
${ }^{4}$ For party affiliation and issue positions, which are each measured by one ordinal variable, we also ran ordered logit analyses (see Table H in the Appendix). The main results of these analyses were similar to those of the OLS regression analyses presented below.
} 
with Hypothesis 1c, candidate sociodemographic characteristics are considered the least. Of the sociodemographic characteristics, education plays the most important role, followed by age and gender. More than 58 percent of the respondents (see Table D), state that gender does not play a role at all when deciding whom they will vote for. This confirms other research suggesting that gender does not have a major impact on citizens' candidate preference (e.g. Campbell and Cowley 2014; Coffé and TheissMorse 2016; Dolan and Lynch 2014; Trent et al. 2001).

Overall, the data thus show that the characteristics which contain the most direct politically relevant information are the most influential. The correlations between the different characteristics (see Table $\mathrm{G}$ in the Appendix) suggest that the candidate issue positions and competence and experience have the strongest link (correlation=.50), indicating a tendency among those who say to consider candidate competence and experience when deciding whom to support to also consider their issue positions. The correlation is the weakest (.15) between considering candidate party affiliation and their sociodemographic profile.

\section{Explanatory Analyses}

Turning to a detailed test of our expectations, Figure 1 shows scatter plots of the point estimates of our main explanatory variables resulting from our multivariate OLS regressions for the four candidate characteristics (see Table $\mathrm{E}$ in the Appendix for the full models).

The likelihood of relying on candidate issue positions and competence and experience is also positively influenced by media attention. The more voters followed the campaign via online media (and marginally significantly also traditional media), the more likely they are to say that their voting behaviour was influenced by candidate issue positions. Media attention also matters positively for the likelihood of considering candidate competence and experience when deciding whom to vote for, but here it is the extent to which voters followed the traditional media that matters strongly. Political interest as a measure of political sophistication does not seem to influence the likelihood of voters to consider certain candidate characteristics once controlling for political knowledge and media attention. 
Figure 1. Coefficients (With 95\% Confidence Intervals) for Main Explanatory Variables of Ordinary Least Squares Regression Analyses Explaining the Likelihood That Various Candidate Characteristics Influenced Voters' Choice of a Candidate.
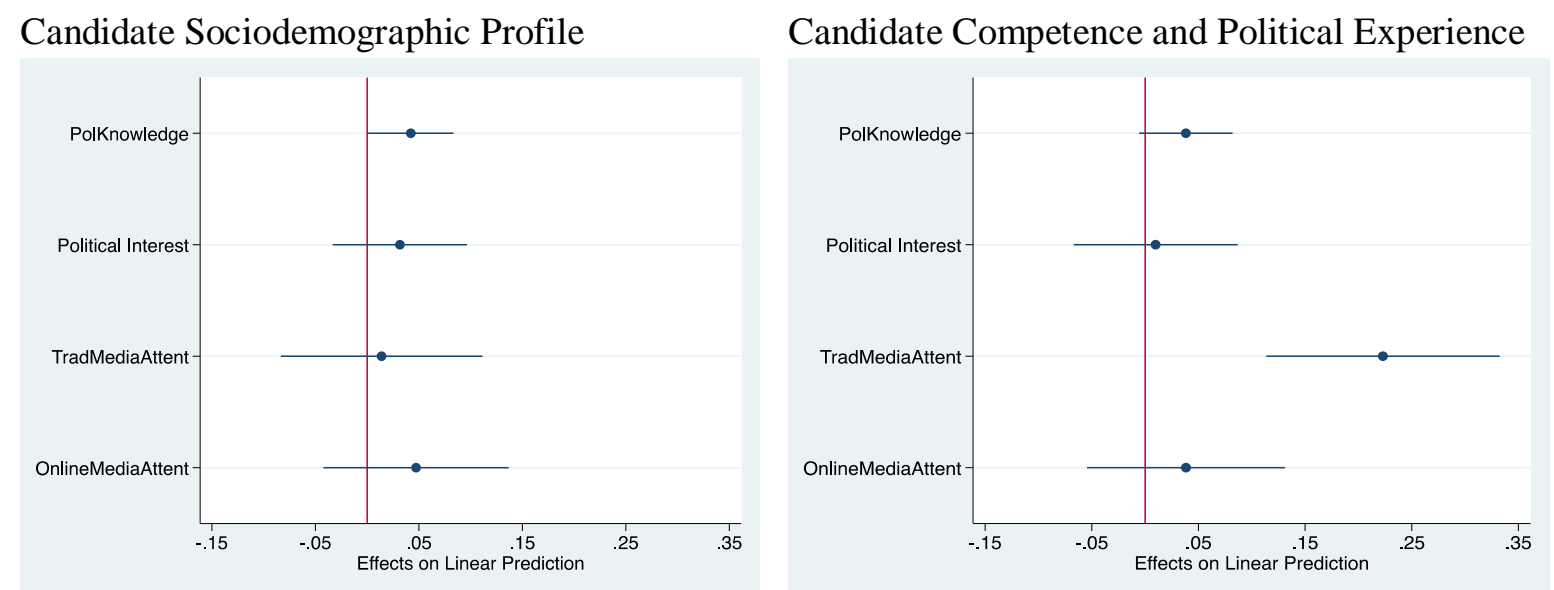

Candidate Issue Positions
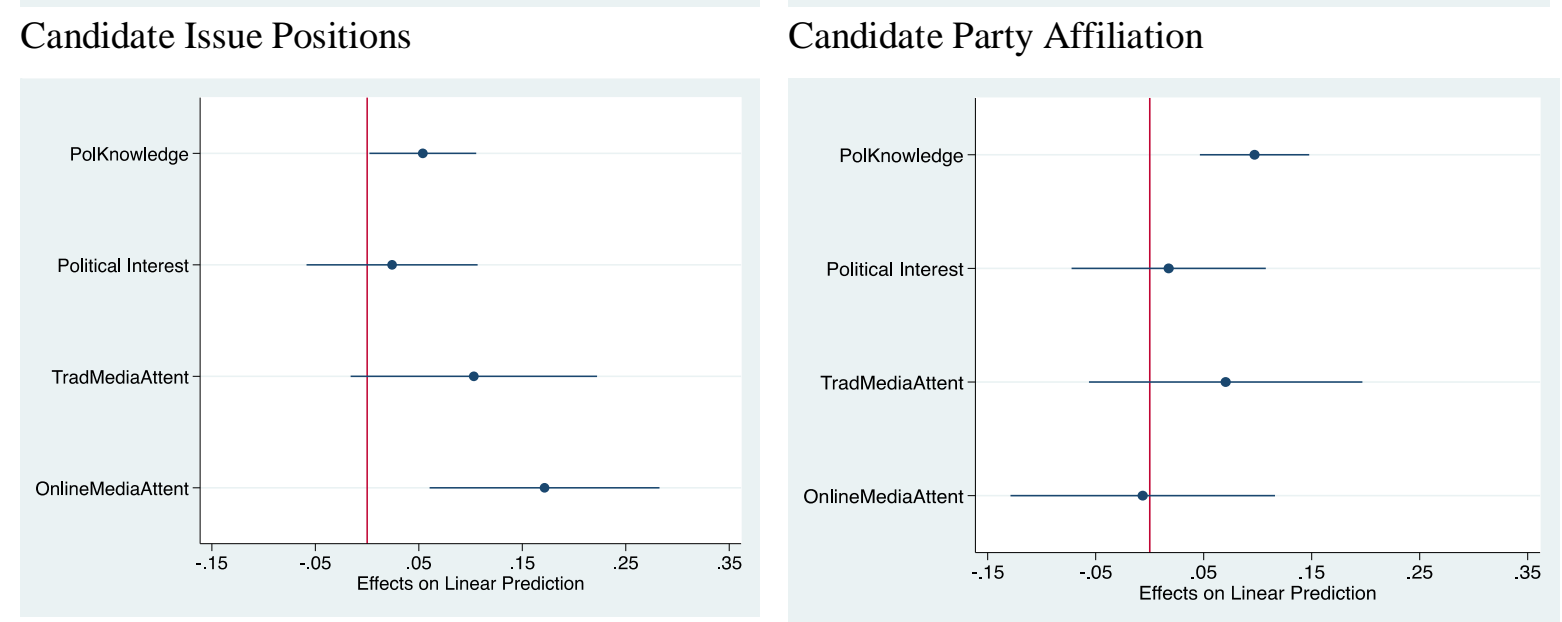

The finding that politically sophisticated voters tend to rate all types of candidate characteristics as more important than less sophisticated voters, leads us to further investigations which examine the relative importance of the different candidate characteristics, and how these relative ratings are influenced by political sophistication. In other words, do politically sophisticated voters find candidate sociodemographic profile more important compared with the other candidate characteristics than voters with lower levels of political sophistication? To that end, we calculated for each voter how important they considered each particular characteristic and compare the importance of each particular characteristic with the average rating of the other candidate characteristics. ${ }^{5}$ Figure 2 presents scatter

${ }^{5}$ For each respondent the relative importance of a candidate characteristic $\left(R I C C_{y}\right)$ is given by:

$$
R I C C_{y}=\frac{I C C_{y}-\overline{I C C}}{\overline{I C C}}
$$

where $I C C_{y}$ stands for the influence of candidate characteristic $y$; and $\overline{I C C}$ for the average importance of all other candidate characteristics (thus all characteristics except $y$ ) defined as:

$$
\overline{I C C}=\frac{\sum I C C}{3}
$$


plots of the point estimates for the effect of our political sophistication variables on the relative importance attributed to the four different candidate characteristics (see Table F in the Appendix for the results of the full OLS regression models).

Figure 2. Coefficients (With 95\% Confidence Intervals) for Main Explanatory Variables of Ordinary Least Squares Regression Analyses Explaining the Relative Influence of Various Candidate Characteristics on Voters' Choice of a Candidate.

Candidate Sociodemographic Profile

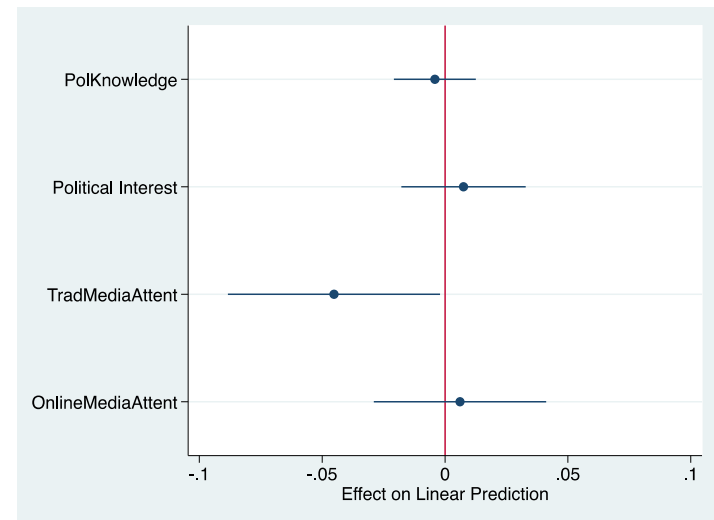

Candidate Issue Positions

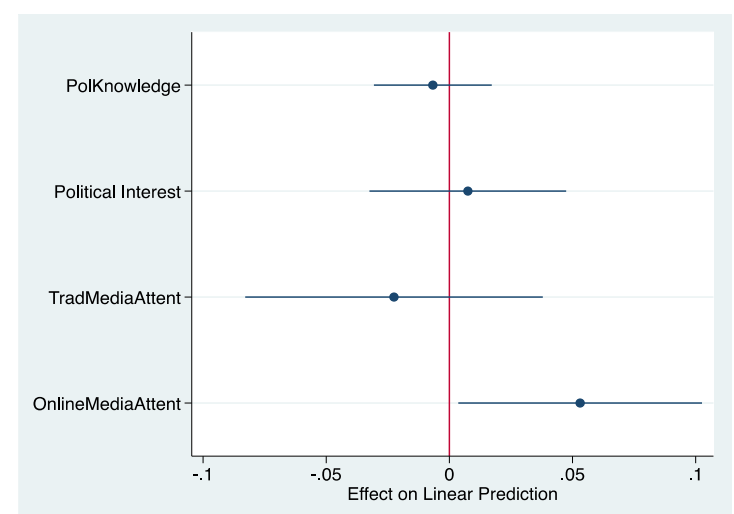

Candidate Competence and Political Experience

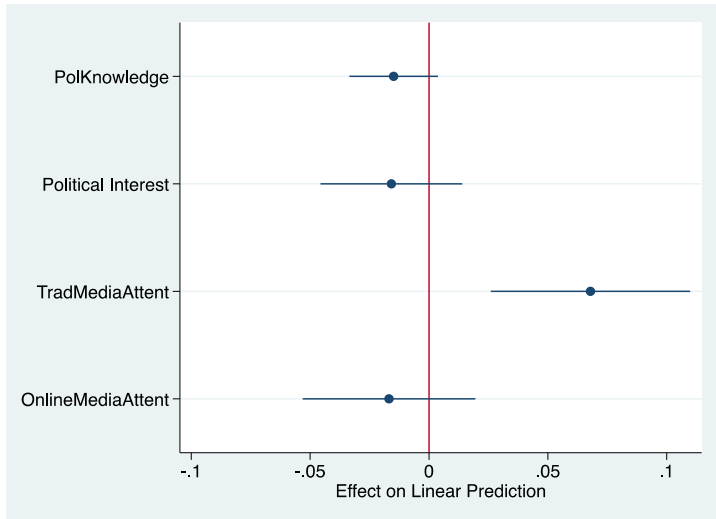

Candidate Party Affiliation

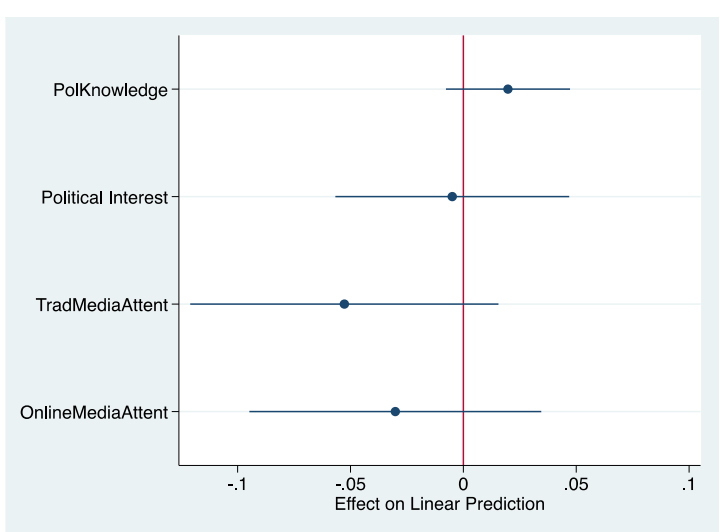

Figure 2 shows that the relative importance of specific characteristics is mainly influenced by media attention. The more attention that voters pay to the coverage of parliamentary elections in the traditional media, the more likely they are to find candidate competence and experience more important than other characteristics. Similarly, the more attention that voters pay to the coverage of parliamentary elections in online media sources, the more likely they are to find candidate issue positions more important than other characteristics. These findings indicate that politically sophisticated voters are more likely to

where $\sum I C C$ is the sum of influence of all other candidate characteristics (thus all characteristics except $y$ ) divided by three, which is the total number of candidate characteristics minus 1 (thus the total number of other characteristics). 
emphasize more complex candidate characteristics such as candidate competence and experience, which is in line with our originally formulated Hypothesis 2. The analyses also show that voters who pay little attention to the coverage of the parliamentary elections in traditional media are significantly more likely to rely on candidate sociodemographic profile than other candidate characteristics. This seems to suggest that politically sophisticated voters (at least when measured by exposure to traditional media) rely less on candidate characteristics that are relatively easy to ascertain.

The results indicate that political sophistication has a significant and positive impact on the likelihood of saying to rely on all four candidate characteristics when deciding whom to support. The particular measures of political sophistication that matter, however, differ between the different candidate characteristics. As can be seen from Figure 1, factual political knowledge has the most consistent impact and has a significant $(\mathrm{p}<.05)$ and positive impact on voters' likelihood of relying on all candidate characteristics investigated in the study, except candidate competence and experience (on which it has a marginally significant ( $\mathrm{p}<10)$ impact). Hence, it appears as if the politically knowledgeable voters are more likely to emphasise both characteristics that are difficult to ascertain and/or that contain highly relevant political information, and characteristics that are easy to ascertain and/or that contain little political information than voters who are less political knowledgeable. While these findings confirm Hypothesis 2, they reject the anticipated non-significant effect of political sophistication on candidate characteristics that are easy to ascertain (Hypothesis 3).

\section{CONCLUSION AND DISCUSSION}

The aim of the current study was to systematically investigate which candidate characteristics voters emphasise when deciding whom to vote for, and to what extent this differs depending on citizens' levels of political sophistication. Overall, the analyses show that voters argue to be most influenced by candidate characteristics containing the most direct politically relevant information when deciding which candidate to support. Candidate party affiliation is the most emphasised characteristic, but candidate issue positions also play a major role. By contrast, candidate sociodemographic characteristics have, according to voters themselves, little relevance when they decide whom to support. As such, the current study adds to the empirical study on the personalization of politics and somewhat challenges the claim of the (growing) importance of personal qualities and characteristics, as it suggests that it is (still) parties and candidate party affiliation that play the most important role for voters - at least when they explain their own voting behaviour.

The study also shows that political sophistication does have an impact on which characteristics voters say to rely on when deciding whom to support. In particular, political sophistication has a positive effect on all candidate characteristics considered in the current study. Voters who are politically sophisticated are more likely to find both characteristics that are easy to ascertain and more complex candidate characteristics important when deciding whom to support compared with those who are not 
politically sophisticated. Sophisticated voters thus seem to consider a wider variety of candidate characteristics when deciding whom to support. This is in line with the argument put forward by Sniderman et al. (1991), and might reflect politically sophisticated voters' greater awareness of the complexity of the vote choice and multidimensionality of political representation. When examining the relative importance of each characteristic (relative to the other characteristics) a different pattern occurs. Political sophistication decreases the likelihood of finding sociodemographic characteristics important but increases the likelihood of saying that political competence and experience as well as policy issues matter.

Our study also indicates that the way that political sophistication is measured matters. We found that factual knowledge had the most consistent (and positive) effect on the likelihood of stating to relying on all candidate characteristics considered in the study except the competence and experience scale. Substantively, however, the effect was overall stronger for media attention than for political knowledge. When studying the relative importance of the different characteristics (relative to the importance of other characteristics), media attention also mattered the most. Traditional media exposure has a negative effect on the relative importance of candidate sociodemographic profile, but a positive impact on the likelihood of finding political competence and experience more important than other candidate characteristics. Similarly, online media attention increases the likelihood of saying to rely more on policy positions than other candidate characteristics.

Overall thus, our study shows that different patterns occur whether one studies the overall importance respondents attribute to different candidate characteristics when deciding whom to support, or whether one focuses on the relative importance attributed to various candidate characteristics. In addition, our results highlight the relevance of including different measures of political sophistication in empirical studies. It may also help to explain some of the conflicting results found in the research on the link between candidate or leader characteristics and political sophistication, since different studies use different measures of political sophistication.

Since our study focuses on only one country, Finland, the question remains to what extent the findings are generalizable to other (post-industrialized) countries. The Finnish electoral system offers voters a demanding decision-making context, which is expected to highlight the importance of information shortcuts and the impact of political sophistication. Political sophistication may thus have a less differentiating effect in for example flexible list systems such as the Belgian and Danish electoral systems. Given that Finland has a tradition of strong female political representation (Statistics Finland 2015), the sociodemographic profile of candidates (and in particular their gender) may play a smaller role when voters decide whom to support in Finland compared with countries with lower levels of female representation in parliament.

For now, we can conclude that in a highly candidate-centred political context such as Finland, it is (still) - according to the voters themselves - candidate party affiliation that matters most when they decide whom to support. Simultaneously and systematically investigating the influence of various 
candidate characteristics - both in overall and relative sense - made it possible to directly compare which characteristics voters emphasise the most and how the importance compares to one another. As such, it offers a valuable addition to the existing studies on the topic at hand. These studies generally rely on survey experiments and mostly only deal with one (typically sociodemographic) characteristic, leaving party affiliation and issue positions out of the contest. While survey experiments provide valuable evidence, the controlled environment in which they take place does not reflect and represent real-world elections. While having its own shortcomings (e.g. through possibly providing socially desirable answers, answers that are a result of rationalization, or not knowing or remembering which characteristics mattered precisely when deciding whom to vote for), the use of survey questions does contributes with a complementary perspective and improves our understanding of which candidate characteristics voters consider the most in real-life situations.

\section{REFERENCES}

Adam, Silke and Michaela Maier. 2010. Personalization of Politics. A Critical Review and Agenda for Research. Annals of the International Communication Association 34(1): 213-257.

Albright, Jeremy J. 2009. Does Political Knowledge Erode Party Attachments?: A Review of the Cognitive Mobilization Thesis. Electoral Studies 28: 248-260.

Arnesen, Sveinung, Dominik Duell and Mikael Poul Johannesson. 2019. Do Citizens Make Inferences From Political Candidate Characteristics When Aiming For Substantive Representation? Electoral Studies 57: 46-60.

Arter, David. 2014. Clowns, 'Alluring Ducks' and 'Miss Finland 2009': The Value of 'Celebrity Candidates' in an Open- List PR Voting System. Representation 50(4): 453- 470.

Bafumi, Joseph and Robert Y. Shapiro. 2009. A New Partisan Voter. Journal of Politics 71 (1): 1-24.

Bartels, Larry M. 1996. Uninformed Votes: Information Effects in Presidential Elections. American Journal of Political Science 40(1): 194-230.

Bartels, Larry. 2000. Partisanship and Voting Behavior, 1952-1996. American Journal of Political Science 44: 35-50.

Berggren, Niklas, Henrik Jordahl and Pani Poutvaara. 2010. The Looks of a Winner: Beauty and Electoral Success. Journal of Public Economics 94(1-2): 8-15.

Blais, André, Pierre Martin and Richard Nadeau. 1998. Can People Explain Their Own Vote? Introspective Questions as Indicators of Salience in the 1995 Quebec Referendum on Sovereignty. Quality and Quantity, 32(4), 355-366.

Bolzendahl, Catherine and Clem Brooks. 2007. Women's Political Representation and Welfare State Spending in 12 Capitalist Democracies. Social Forces 85(4): 1509-1534.

Boonen, Joris, Eva Falk Pedersen and Marc Hooghe. 2017. The Effect of Political Sophistication and Party Identification on Voter-Party Congruence. A Comparative Analysis of 30 Countries. Journal of Elections, Public Opinion and Parties 27(3): 311-329.

Brown, Steven D., Ronald D. Lambert, Barry J. Kay and James E. Curtis. 1988. The Eye of the Beholder: Leader Images in Canada. Canadian Journal of Political Science 21(4): 729-755.

Campbell, Rosie and Philip Cowley. 2014. What Voters Want: Reactions to Candidate Characteristics in a Survey Experiment. Political Studies 62(4): 745-765.

Catellani, Patrizia and Augusta Isabella Alberici. 2012. Does the Candidate Matter? Comparing the Voting Choice of Early and Late Deciders. Political Psychology 33(5): 619-634.

Childs, Sarah. 2004. A Feminised Style of Politics? Women MPs in the House of Commons. British Journal of Politics and International Relations 6(1): 3-19.

Clifford, Scott. 2014. Linking Issue Stances and Trait Inferences: A Theory of Moral Exemplification. Journal of Politics 76 (3): 698-710. 
Coffé, Hilde and Elizabeth Theiss-Morse. 2016. The Effect of Political Candidates' Occupational Background on Voters' Perceptions of and Support for Candidates. Political Science 68(1): 5577.

Collignon, Sofia and Javier Sajuria. 2018. Local Means Local, Does It? Regional Identification and Preferences for Local Candidates. Electoral Studies 56: 170-178.

Cowley, Philip. 2013. Why Not Ask the Audience? Understanding the Public's Representational Priorities. British Politics 8(2): 138-163.

Cutler, Fred. 2002. The Simplest Shortcut of All: Sociodemographic Characteristics and Electoral Choice. Journal of Politics 64(2): 466-490.

Dahlgaard, Jens Olav. 2016. You Just Made It: Individual Incumbency Advantage Under Proportional Representation. Electoral Studies 44: 319-328.

Dalton, Russell J. 1984. Cognitive Mobilization and Partisan Dealignment in Advanced Industrial Democracies. Journal of Politics 46: 264-284.

Dalton, Russell J. 2007. Partisan Mobilization, Cognitive Mobilization, and the Changing American Electorate. Electoral Studies 26: 274-286.

Dalton, Russell J. and Martin P. Wattenberg. 2000. Parties Without Partisans: Political Change in Advanced Industrial Democracies. Oxford: Oxford University Press.

Delli Carpini, Michael and Scott Keeter. 1996. What Americans Know About Politics and Why It Matters. New Haven, CT, USA: Yale University Press.

Dolan, Kathleen. 2014. Gender Stereotypes, Candidate Evaluations, and Voting for Women Candidates. Political Research Quarterly 67(1): 96-107.

Dolan, Kathleen and Timothy Lynch. 2014. It Takes a Survey: Understanding Gender Stereotypes, Abstract Attitudes and Voting for Women Candidates. American Politics Research 42(4): 656676.

Franchino, Fabio and Francesco Zucchini. 2015. Voting in a Multi-Dimensional Space: a Conjoint Analysis Employing Valence and Ideology Attributes of Candidates. Political Science Research and Methods 3(2): 221-241.

Fridkin, Kim L. and Patrick J. Kenney. 2011. The Role of Candidate Traits in Campaigns. Journal of Politics 73(1): 61-73.

Funk, Carolyn L. 1997. Implications of Political Expertise in Candidate Trait Evaluations. Political Research Quarterly 50(3): 675-697.

Garzia, Diego. 2014. Personalization of Politics and Electoral Change. Basingstoke: Palgrave McMillan.

Goren, Paul. 1997. Political Expertise and Issue Voting in Presidential Elections. Political Research Quarterly 50(2): 387-412.

Grönlund, Kimmo and Elina Kestilä-Kekkonen. 2015. Finnish National Election Study 2015 [dataset]. Finnish Social Science Data Archive. http://urn.fi/urn:nbn:fi:fsd:TFSD3067 [Retrieved on 29 November 2018]

Hayes, Danny. 2011. When Gender and Party Collide: Stereotyping in Candidate Trait Attribution. Politics and Gender 7 (2): 133-65.

Hayes, Danny and Jennifer L. Lawless. 2016. Women on the Run. Gender, Media and Political Campaigns in a Polarized Era. Cambridge: Cambridge University Press.

Isotalo, Veikko, Theodora Järvi and Åsa von Schoultz (2019). The Finnish Voter 2003-2019. Helsinki: Ministry of Justice.

Johns, Robert and Mark Shephard. 2007. Gender, Candidate Image and Electoral Preference. British Journal of Politics and International Relations 9: 434-460.

Karvonen, Lauri. 2010. The Personalization of Politics. A Study of Parliamentary Democracies. Colchester: ECPR Press. Monographs.

Kelley, Stanley Jr. 1983. Interpreting Elections. Princeton: Princeton University Press.

Kevins, Anthony. 2019. Race, Class, or Both? Responses to Candidate Characteristics in Canada, the UK, and the US. Politics, Groups, and Identities. Published Online First. DOI: 10.1080/21565503.2019.1636833

Kim, Do-Kyung. 2006. Political Sophistication and Partisan Cues: Insight from South Korea's 2002 Presidential Election. PhD Dissertation, University of Tennessee.

Kirkland, Patricia A. and Alexander Coppock. 2018. Candidate Choice Without Party Labels. Political 
Behavior 40(3): 571-591.

Koch, Jeffrey. 2002. Gender Stereotypes and Citizens' Impression of House Candidates' Ideological Orientations. American Journal of Political Science 46(2): 453-462.

Lau, Richard R. and David P. Redlawsk. 2001. Advantages and Disadvantages of Cognitive Heuristics in Political Decision Making. American Journal of Political Science 45(4): 951-971.

Lau, Richard R. and David P. Redlawsk. 2006. How Voters Decide. Information Processing During Election Campaigns. New York, NY: Cambridge University Press.

Lau, Richard R., Parina Patel, Dalia F. Fahmy and Robert R. Kaufman. 2013. Correct Voting across Thirty-Three Democracies: A Preliminary Analysis. British Journal of Political Science 44(2): 239-259.

Lenz, Gabriel S. and Chappell Lawson. 2011. Looking the Part: Television Leads Less Informed Citizens to Vote Based on Candidates' Appearance. American Journal of Political Science 55(3): 574-89.

Lovenduski, Joni. 2005. Feminizing Politics. Cambridge: Polity Press.

Luskin, Robert. 1990. Explaining Political Sophistication. Political Behavior 12(4): 331-361.

Macdonald, Stuart Eliane, George Rabinowitz and Ola Listhaug. 1995. Political sophistication and Models of Issue Voting. British Journal of Political Science 25: 453-483.

Marsh, Michael. 1985. The Voters Decide: Preferential Voting in European List Systems. European Journal of Political Research 13(4): 365-378.

McAllister, Ian. 2007. The Personalization of Politics. In Russell J. Dalton and Hans-Dieter Klingemann, eds., Oxford Handbook of Political Behavior. Oxford: Oxford University Press. Pp. 571-588.

McElroy, Gail and Michael Marsh. 2010. Candidate Gender and Voter Choice: Analysis from a Multimember Preferential Voting System. Political Research Quarterly 63(4): 822-33.

Miller, Arthur H., Martin P. Wattenberg and Oksana Malanchuk. 1986. Schematic Assessments of Presidential Candidates. American Political Science Review 80(2): 521-540.

Nisbett, Richard E. and Timothy D. Wilson 1977. Telling More Than We Can Know: Verbal Reports on Mental Processes. Psychological Review 84(3): 231-259.

Norris, Pippa. 1996. Women Politicians: Transforming Westminster? Parliamentary Affairs 49(1): 89102.

Pedersen, Rasmus T., Jens Olav Dahlgaard and Manuele Citi. 2019. Voter Reactions to Candidate Background Charactersticis Depend on Candidate Policy Positions. Electoral Studies 61.

Peterson, David A. M. 2005. Heterogeneity and Certainty in Candidate Evaluations. Political Behavior 27(1): 1-24.

Popkin, Samuel L. 1991. The Reasoning Voter. Chicago: University of Chicago Press.

Put, Gert-Jan and Bart Maddens. 2015. The Effect of Municipal Size and Local Office on the Electoral Success of Belgian/Flemish Election Candidates: A Multilevel Analysis. Government and Opposition 59(4): 607-628.

Rahn, Wendy M., Jon A. Krosnick and Marijke Breuning. 1994. Rationalization and Derivation Processes in Survey Studies of Political Candidate Evaluation. American Journal of Political Science 38(3): 582-600.

Rosenthal, Cindy Simon. 1995. The Role of Gender in Descriptive Representation. Political Research Quarterly 48(3): 599-611.

von Schoultz, Âsa. 2018. Electoral Systems in Context: Finland. In Erik S. Herron, Robert J. Pekkanen and Matthew S. Shugart (Eds.) Oxford Handbook of Electoral Systems. Oxford: Oxford University press. Pp. 601-626.

Shugart, Matthew S., Melody E. Valdini and Kati Suominen. 2005. Looking for Locals: Voter Information Demands and Personal Vote-Earning Attributes of Legislators under Proportional Representation. American Journal of Political Science. 49(2):437-49.

Singh, Shane P. 2010. Contextual Influences on the Decision Calculus: A Cross-National Examination of Proximity Voting. Electoral Studies 29(3): 425-434.

Sniderman, Paul M., James M. Glaser and Robert Griffin. 1991. Information and Electoral Choice. In Paul M. Sniderman, Richard A. Brody and Philip E. Tetlock (Eds.) Reasoning and Choice: Explorations in Political Psychology. Cambridge: Cambridge University Press. Pp. 164-178.

Statistics Finland. 2015. Background Analysis of Candidates and Elected MPs in the Parliamentary 
Elections 2015. Retrieved from https://www.stat.fi/til/evaa/2015/evaa 2015 2015-0430_kat_001_en.html

Tavits, Margit. 2010. Effect of Local Ties on Electoral Success and Parliamentary Behaviour. The Case of Estonia. Party Politics 16(2): 215-35.

Trent, Judith S., Cady Short-Thompson, Paul A. Mongeau, Andrew K. Nusz and Jimmie D. Trent. 2001. Image, Media Bias, and Voter Characteristics. The Ideal Candidate from 1988-2000. American Behavioural Scientist 44(12): 2101-2124.

Wängnerud, Lena. 2009. Women in Parliaments: Descriptive and Substantive Representation. Annual Review of Political Science 12: 51-69.

Wattenberg, Martin P. 1991. The Rise of Candidate-Centered Politics. Cambridge, MA: Harvard University Press.

Zaller, John R. 1990. Political Awareness, Elite Opinion Leadership, and the Mass Survey Response. Social Cognition 8: 125-153.

Zaller, John R. 1992. The Nature and Origins of Mass Opinion. New York, NY: Cambridge University Press. 


\section{Appendix}

Table A. Factor Loadings Rotated Principal Component Factor Analysis Candidate Characteristics $(\mathrm{N}=1,131)$

\begin{tabular}{lcc}
\hline & Factor 1 & Factor 2 \\
\hline Sociodemographic Profile & .05 & \\
$\quad$ Age & -.00 & .77 \\
$\quad$ Gender & .20 & .81 \\
$\quad$ Education & & \\
Competence and Experience & .86 & .02 \\
$\quad$ Reliability & .86 & .03 \\
$\quad$ Ability to Manage Things & .64 & .17 \\
$\quad$ Public Speaking and Presentation Skills & .68 & .15 \\
$\quad$ Prior Experience in Politics & .68 & .08 \\
Issue Positions & .37 & .19 \\
Party Affiliation & & \\
Eigenvalue & 3.20 & 1.59 \\
\hline Source: 2015 Finnish Election Survey & &
\end{tabular}

Table B. Summary of Control Variables

\begin{tabular}{|c|c|c|}
\hline Variables & Question & (Recoded) Categories \\
\hline Gender & What is your gender? & $\begin{array}{l}\text { (1) Female } \\
\text { (0) Male }\end{array}$ \\
\hline $\begin{array}{l}\text { Age } \\
\text { (and its squared Value) }\end{array}$ & What is your year of birth? & Continuous variable \\
\hline Education & $\begin{array}{l}\text { What is the highest level of } \\
\text { education or degree you have } \\
\text { completed? }\end{array}$ & $\begin{array}{l}\text { (1) A polytechnic/university of applied } \\
\text { sciences or university education } \\
\text { (0) Upper secondary level education or lower }\end{array}$ \\
\hline Occupational Status & $\begin{array}{l}\text { What is your occupational } \\
\text { status? }\end{array}$ & $\begin{array}{l}\text { (1) An intermediate level job, managers and } \\
\text { professional employees (higher white collar } \\
\text { employment) } \\
\text { (0) All others (including students, retired and } \\
\text { unemployed people) }\end{array}$ \\
\hline Marital Status & What is your marital status? & $\begin{array}{l}\text { (1) Married or registered partnership } \\
\text { (0) Other }\end{array}$ \\
\hline Church Attendance & $\begin{array}{l}\text { Apart from weddings, funerals } \\
\text { etc., how often do you go to } \\
\text { church? }\end{array}$ & $\begin{array}{l}\text { (1) Never (reference category) } \\
\text { (2) Once a year } \\
\text { (3) Regularly (2-11 times a year) } \\
\text { (4) At least once a month }\end{array}$ \\
\hline $\begin{array}{l}\text { Left/Right Self } \\
\text { Position }\end{array}$ & $\begin{array}{l}\text { Using the left-right scale, where } \\
\text { would you place yourself? }\end{array}$ & $\begin{array}{l}\text { (1) Left position - score } 0 \text { to } 3 \text { (reference } \\
\text { category) } \\
\text { (2) Middle position - score } 4 \text { to } 6 \\
\text { (3) Right position - score } 7 \text { to } 10 \\
\text { (4) Don't know }\end{array}$ \\
\hline Strength of Party ID & $\begin{array}{l}\text { How stable is your political party } \\
\text { identification? }\end{array}$ & $\begin{array}{l}\text { Continuous variable: } \\
\text { (1) Not at all stable to (4) Completely stable }\end{array}$ \\
\hline
\end{tabular}


Table C. Descriptive Statistics for All Explanatory and Control Variables $(\mathrm{N}=1,173)$

\begin{tabular}{lccc}
\hline Variables & Range & $\begin{array}{c}\text { Mean/ } \\
\text { Proportion }\end{array}$ & $\begin{array}{c}\text { Standard } \\
\text { Deviation }\end{array}$ \\
\hline Political Knowledge & $0-4$ & 2.80 & 1.13 \\
Political Interest & $1-4$ & 2.98 & .77 \\
Traditional Media Attention & $1-4$ & 2.19 & .54 \\
Online Media Attention & $1-4$ & 1.55 & .58 \\
& & & \\
Female & $0 / 1$ & $50.5 \%$ & \\
Age & $18-93$ & 46.8 & .25 \\
Higher Education & $0 / 1$ & $36.3 \%$ & \\
Higher White Collar Work & $0 / 1$ & $28.0 \%$ & \\
Married & $0 / 1$ & $44.7 \%$ & \\
Church Attendance (ref. Never) & & & \\
$\quad$ Once a year & $0 / 1$ & $26.9 \%$ & \\
$\quad$ 2-11 times a year & $0 / 1$ & $25.8 \%$ & \\
$\quad$ At least once a month & $0 / 1$ & $9.0 \%$ & \\
Left-Right Self Position (ref. Left position) & & & \\
$\quad$ Middle Position & $0 / 1$ & $41.2 \%$ & \\
$\quad$ Right position & $0 / 1$ & $37.7 \%$ & \\
$\quad$ Don't know & $0 / 1$ & $6.9 \%$ & .92 \\
Strength Party Identification & $1-4$ & 2.9 & \\
\hline
\end{tabular}

Source: 2015 Finnish Election Survey 
Table D. Percentages Per Answer Category For Importance Candidate Characteristics

\begin{tabular}{lccccc}
\hline & Not at all & Somewhat & A lot & Decisive & Total N \\
\hline Sociodemographic Profile & 47.3 & 34.2 & 14.0 & 4.5 & 1,171 \\
$\quad$ Age & 58.3 & 23.1 & 11.1 & 7.5 & 1,169 \\
$\quad$ Gender & 35.2 & 35.2 & 23.0 & 6.6 & 1,169 \\
$\quad$ Education & & & & & \\
Competence and Experience & 8.1 & 19.0 & 43.7 & 29.2 & 1,159 \\
$\quad \begin{array}{l}\text { Reliability } \\
\text { Ability to Manage Things }\end{array}$ & 7.3 & 15.8 & 44.7 & 32.2 & 1,167 \\
$\quad \begin{array}{l}\text { Public Speaking and } \\
\quad \text { Presentation Skills }\end{array}$ & 16.9 & 30.8 & 37.5 & 14.7 & 1,161 \\
$\quad \begin{array}{l}\text { Prior Experience in Politics } \\
\quad\end{array}$ & 22.2 & 32.1 & 29.7 & 16.0 & 1,165 \\
Issue Positions & 6.9 & 17.9 & 40.9 & 34.4 & 1,170 \\
$\quad$ & 8.6 & 19.6 & 26.9 & 45.0 & 1,166 \\
\hline Party Affiliation & & & &
\end{tabular}

Source: 2015 Finnish Election Survey

Note: All results are for weighted data. 
Table E. Ordinary Least Squares Regression Analyses Explaining the Likelihood That Various Candidate Characteristics Influenced Voters' Choice of a Candidate (Robust Standard Errors between brackets).

\begin{tabular}{|c|c|c|c|c|c|c|c|c|}
\hline \multirow[b]{2}{*}{ Political Knowledge } & \multicolumn{2}{|c|}{$\begin{array}{c}\text { Sociodemographic } \\
\text { Profile }\end{array}$} & \multicolumn{2}{|c|}{$\begin{array}{c}\text { Competence and } \\
\text { Experience }\end{array}$} & \multicolumn{2}{|c|}{ Policy Positions } & \multicolumn{2}{|c|}{ Party Affiliation } \\
\hline & $.04 *$ & $(.02)$ & $.04 \dagger$ & $(.02)$ & $.05^{*}$ & $(.03)$ & $.10 * * *$ & $(.03)$ \\
\hline Political Interest & .03 & $(.03)$ & .01 & $(.04)$ & .02 & $(.04)$ & .02 & $(.05)$ \\
\hline Traditional Media Attention & .01 & $(.05)$ & $.22 * * *$ & $(.06)$ & $.10 \dagger$ & $(.06)$ & .07 & $(.06)$ \\
\hline Online Media Attention & .05 & $(.05)$ & .04 & $(.05)$ & $.17 * *$ & $(.06)$ & -.01 & $(.06)$ \\
\hline Female & $.23 * * *$ & $(.04)$ & .01 & $(.05)$ & .03 & $(.06)$ & .02 & $(.06)$ \\
\hline Age & -.01 & $(.01)$ & .00 & $(.01)$ & -.01 & $(.01)$ & $-.02 \dagger$ & $(.01)$ \\
\hline Age Squared & .00 & $(.00)$ & -.00 & $(.00)$ & .00 & $(.00)$ & .00 & $(.00)$ \\
\hline Higher Education & $.13 * *$ & $(.05)$ & .00 & $(.05)$ & $.12 *$ & $(.06)$ & -.09 & $(.06)$ \\
\hline Higher White Collar Work & -.01 & $(.05)$ & -.05 & $(.05)$ & -.05 & $(.06)$ & -.07 & $(.07)$ \\
\hline Married & $-.10^{*}$ & $(.05)$ & -.04 & $(.05)$ & .00 & $(.06)$ & -.07 & $(.06)$ \\
\hline \multicolumn{9}{|l|}{ Church Attendance (ref. Never) } \\
\hline Once a year & $.09 \dagger$ & $(.05)$ & .04 & $(.06)$ & $.13 \dagger$ & $(.07)$ & .06 & $(.07)$ \\
\hline 2-11 times a year & $.09 \dagger$ & $(.06)$ & $.19 * *$ & $(.06)$ & .11 & $(.07)$ & .06 & $(.08)$ \\
\hline At least once a month & .00 & $(.08)$ & $.17 *$ & $(.08)$ & $.21 *$ & $(.09)$ & .08 & $(.10)$ \\
\hline \multicolumn{9}{|c|}{ Left-Right Position (ref. Left Position) } \\
\hline Middle Position & -.04 & $(.07)$ & -.04 & $(.07)$ & $-.28 * * *$ & $(.08)$ & $-.22 *$ & $(.09)$ \\
\hline Right position & .04 & $(.07)$ & .11 & $(.08)$ & -.08 & $(.08)$ & -.10 & $(.09)$ \\
\hline Don't know & $-.21 *$ & $(.10)$ & -.10 & $(.11)$ & -.21 & (.14) & -.07 & $(.14)$ \\
\hline Strength Party Identification & .02 & $(.02)$ & .05 & $(.03)$ & .03 & $(.03)$ & $.43 * * *$ & $(.04)$ \\
\hline Constant & $1.40^{* * *}$ & $(.19)$ & $1.76^{* * *}$ & $(.21)$ & $2.61 * * *$ & $(.25)$ & $1.96^{* * *}$ & $(.28)$ \\
\hline R-Squared & \multirow{2}{*}{\multicolumn{2}{|c|}{$\begin{array}{c}.07 \\
1,166\end{array}$}} & \multirow{2}{*}{\multicolumn{2}{|c|}{$\begin{array}{c}.09 \\
1,139\end{array}$}} & \multirow{2}{*}{\multicolumn{2}{|c|}{$\begin{array}{c}.09 \\
1,170\end{array}$}} & \multirow{2}{*}{\multicolumn{2}{|c|}{$\begin{array}{c}.21 \\
1,166\end{array}$}} \\
\hline $\mathrm{N}$ & & & & & & & & \\
\hline
\end{tabular}

Source: 2015 Finnish Election Survey

$* * * \mathrm{p}<.001 ; * * \mathrm{p}<.01 ; * \mathrm{p}<.05 ; \dagger \mathrm{p}<.10$ 
Table F. Ordinary Least Squares Regression Analyses Explaining the Relative Influence of Various Candidate Characteristics on Voters' Choice of a Candidate (Robust Standard Errors between brackets).

\begin{tabular}{|c|c|c|c|c|c|c|c|c|}
\hline \multirow[b]{2}{*}{ Political Knowledge } & \multicolumn{2}{|c|}{$\begin{array}{c}\text { Sociodemographic } \\
\text { Profile } \\
\end{array}$} & \multicolumn{2}{|c|}{$\begin{array}{c}\text { Competence and } \\
\text { Experience } \\
\end{array}$} & \multicolumn{2}{|c|}{ Policy Positions } & \multicolumn{2}{|c|}{ Party Affiliation } \\
\hline & -.00 & $(.01)$ & -.01 & $(.01)$ & -.01 & $(.01)$ & .02 & $(.01)$ \\
\hline Political Interest & .01 & $(.01)$ & -.02 & $(.02)$ & .01 & $(.02)$ & -.00 & $(.03)$ \\
\hline Traditional Media Attention & $-.05 *$ & $(.02)$ & $.07 * *$ & $(.02)$ & -.02 & $(.03)$ & -.05 & $(.03)$ \\
\hline Online Media Attention & .01 & $(.02)$ & -.02 & $(.02)$ & $.05^{*}$ & $(.03)$ & -.03 & $(.03)$ \\
\hline Female & $.08 * * *$ & $(.02)$ & $-.04 \dagger$ & $(.02)$ & -.02 & $(.02)$ & -.04 & $(.03)$ \\
\hline Age & .00 & $(.00)$ & .00 & $(.00)$ & -.00 & $(.00)$ & -.00 & $(.01)$ \\
\hline Age Squared & .00 & $(.00)$ & -.00 & $(.00)$ & -.00 & $(.00)$ & .00 & $(.00)$ \\
\hline Higher Education & $.04 *$ & $(.02)$ & -.01 & $(.02)$ & .04 & $(.03)$ & $-.09 *$ & $(.03)$ \\
\hline Higher White Collar Work & .01 & $(.02)$ & .00 & $(.02)$ & .00 & $(.03)$ & -.03 & $(.04)$ \\
\hline Married & -.03 & $(.02)$ & -.00 & $(.02)$ & .03 & $(.03)$ & .01 & $(.03)$ \\
\hline \multicolumn{9}{|l|}{ Church Attendance (ref. Never) } \\
\hline Once a year & -.01 & $(.02)$ & -.03 & $(.02)$ & .02 & $(.03)$ & -.02 & $(.04)$ \\
\hline 2-11 times a year & -.01 & $(, 02)$ & .03 & $(.02)$ & -.01 & $(.03)$ & -.06 & $(.04)$ \\
\hline At least once a month & -.04 & $(.03)$ & .03 & $(.03)$ & .04 & $(.04)$ & $-.08+$ & $(.04)$ \\
\hline \multicolumn{9}{|c|}{ Left-Right Position (ref. Left Position) } \\
\hline Middle Position & .04 & $(.03)$ & $.05 \dagger$ & $(.03)$ & -.06 & $(.04)$ & -.03 & $(.05)$ \\
\hline Right position & .02 & $(.02)$ & $.06 \dagger$ & (.03) & -.05 & (.04) & -.06 & $(.05)$ \\
\hline Don't know & .00 & $(.06)$ & -.00 & .04 & -.03 & $(.06)$ & .04 & $(.07)$ \\
\hline Strength Party Identification & $-.03 * *$ & $(.01)$ & $-.05 * * *$ & $(.01)$ & $-.08 * * *$ & $(.02)$ & $.17 * * *$ & $(.02)$ \\
\hline Constant & $-.32 * * *$ & $(.09)$ & $\begin{array}{l}.02 \\
\end{array}$ & (.10) & $.52 * * *$ & $(.12)$ & .08 & $(.15)$ \\
\hline R-Squared & \multirow{2}{*}{\multicolumn{2}{|c|}{$\begin{array}{c}.05 \\
1.131\end{array}$}} & \multicolumn{2}{|c|}{.06} & \multicolumn{2}{|c|}{.09} & \multicolumn{2}{|c|}{.11} \\
\hline $\mathrm{N}$ & & & \multicolumn{2}{|c|}{1,131} & \multicolumn{2}{|c|}{1,131} & \multicolumn{2}{|c|}{1,131} \\
\hline
\end{tabular}

Source: 2015 Finnish Election Survey

$* * * \mathrm{p}<.001 ; * * \mathrm{p}<.01 ; * \mathrm{p}<.05 ; \dagger \mathrm{p}<.10$ 
Table G. Correlations Between the Different Candidate Characteristics

\begin{tabular}{lcccc}
\hline & $\begin{array}{l}\text { Sociodemographic } \\
\text { Profile }\end{array}$ & $\begin{array}{l}\text { Competence } \\
\text { and Experience }\end{array}$ & Policy Positions & Party Affiliation \\
\hline $\begin{array}{l}\text { Sociodemographic } \\
\text { Profile }\end{array}$ & 1.00 & & & \\
$\begin{array}{l}\text { Competence and } \\
\text { Experience }\end{array}$ & .23 & 1.00 & & \\
$\begin{array}{l}\text { Policy Positions } \\
\text { Party Affiliation }\end{array}$ & .17 & .50 & 1.00 & \\
\hline
\end{tabular}

Source: 2015 Finnish Election Survey

Table H. Ordered Logit Regression Analyses Explaining the Likelihood That Policy Positions and Party Affiliation Influenced Voters' Choice of a Candidate (Robust Standard Errors between brackets).

\begin{tabular}{|c|c|c|c|c|}
\hline \multirow[b]{2}{*}{ Political Knowledge } & \multicolumn{2}{|c|}{ Policy Positions } & \multicolumn{2}{|c|}{ Party Affiliation } \\
\hline & $.10 \dagger$ & $(.06)$ & $.20 * * *$ & $(.06)$ \\
\hline Political Interest & .07 & $(.09)$ & .03 & $(.10)$ \\
\hline Traditional Media Attention & .19 & $(.14)$ & .15 & $(.14)$ \\
\hline Online Media Attention & $.37 * *$ & $(.13)$ & -.07 & $(.14)$ \\
\hline Female & .05 & $(.12)$ & .03 & $(.13)$ \\
\hline Age & -.02 & $(.02)$ & $-.04 \dagger$ & $(.02)$ \\
\hline Age Squared & .00 & $(.00)$ & $.00 \dagger$ & $(.00)$ \\
\hline Higher Education & $.25 \dagger$ & $(.13)$ & -.19 & $(.13)$ \\
\hline Higher White Collar Work & -.11 & $(.14)$ & -.16 & $(.15)$ \\
\hline Married & -.00 & $(.13)$ & -.14 & $(.13)$ \\
\hline \multicolumn{5}{|l|}{ Church Attendance (ref. Never) } \\
\hline Once a year & .22 & $(.15)$ & .05 & $(.15)$ \\
\hline 2-11 times a year & .24 & $(.16)$ & .09 & $(.17)$ \\
\hline At least once a month & $.46^{*}$ & $(.22)$ & .06 & $(.23)$ \\
\hline \multicolumn{5}{|c|}{ Left-Right Position (ref. Left Position) } \\
\hline Middle Position & $-.58 * *$ & $(.18)$ & $-.45^{*}$ & $(.20)$ \\
\hline Right position & -.14 & $(.18)$ & -.25 & $(.20)$ \\
\hline Don't know & -.45 & $(.30)$ & -.09 & $(.31)$ \\
\hline Strength Party Identification & .08 & $(.08)$ & $.84 * * *$ & $(.08)$ \\
\hline Cut 1 & -1.88 & $(.58)$ & -.48 & $(.63)$ \\
\hline Cut 2 & -.33 & $(.56)$ & 1.15 & $(.63)$ \\
\hline Cut 3 & 1.54 & $(.56)$ & 2.53 & $(.63)$ \\
\hline Pseudo R-Squared & \multicolumn{2}{|c|}{.03} & \multicolumn{2}{|c|}{.09} \\
\hline $\mathrm{N}$ & \multicolumn{2}{|c|}{1,170} & \multicolumn{2}{|c|}{1,166} \\
\hline
\end{tabular}

Source: 2015 Finnish Election Survey

$* * * \mathrm{p}<.001 ; * * \mathrm{p}<.01 ; * \mathrm{p}<.05 ; \dagger \mathrm{p}<.10$ 
